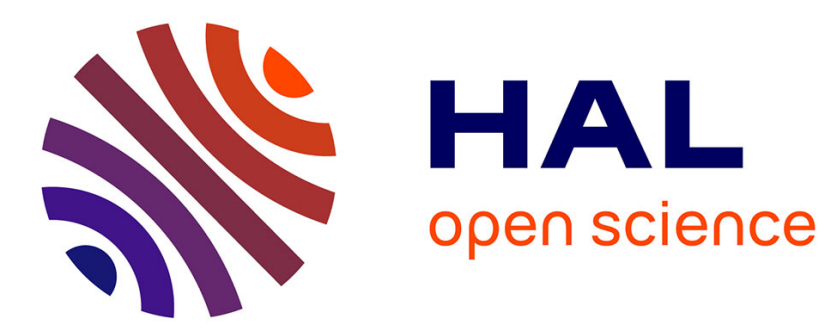

\title{
Experimental and numerical assessment of transient stream-aquifer exchange during disconnection
}

\author{
Agnès Rivière, Julio Goncalves, Anne Jost
}

\section{To cite this version:}

Agnès Rivière, Julio Goncalves, Anne Jost. Experimental and numerical assessment of transient stream-aquifer exchange during disconnection. Workshop "Knowledge's frontiers in water unsaturated hydrogeosystems: interface dynamics, heterogeneities \& couplings", Jun 2019, Orléans, France. . hal02404192

\section{HAL Id: hal-02404192 \\ https://hal.science/hal-02404192}

Submitted on 26 Feb 2020

HAL is a multi-disciplinary open access archive for the deposit and dissemination of scientific research documents, whether they are published or not. The documents may come from teaching and research institutions in France or abroad, or from public or private research centers.
L'archive ouverte pluridisciplinaire HAL, est destinée au dépôt et à la diffusion de documents scientifiques de niveau recherche, publiés ou non, émanant des établissements d'enseignement et de recherche français ou étrangers, des laboratoires publics ou privés. 


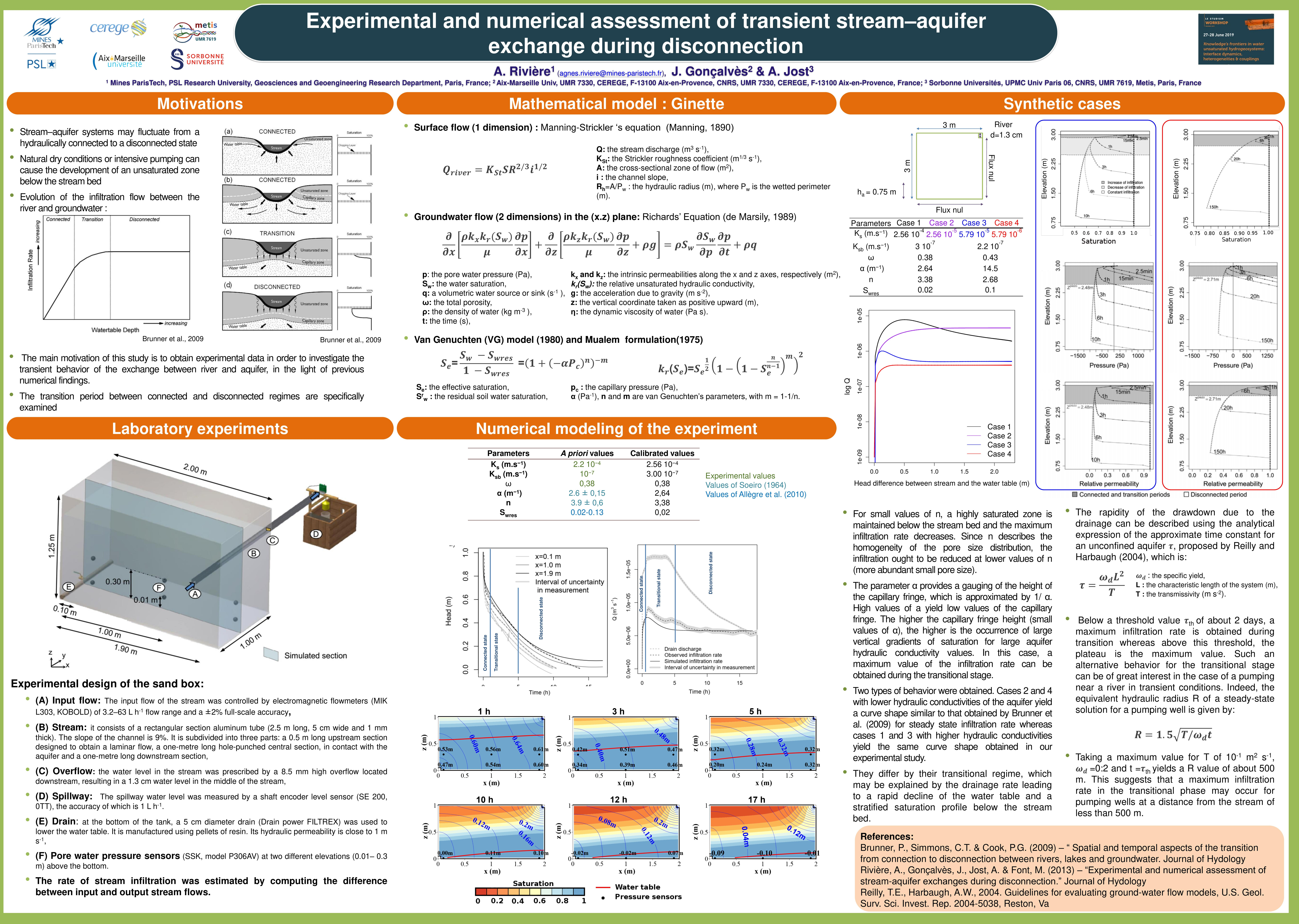

